Zeszyty Naukowe Szkoły Głównej Gospodarstwa Wiejskiego w Warszawie

Problemy Rolnictwa Światowego tom 18 (XXXIII), zeszyt 1, 2018: 121-129

DOI: $10.22630 /$ PRS.2018.18.1.11

Magdalena Kozera-Kowalska ${ }^{1}$, Izabela Hasińska ${ }^{2}$

Uniwersytet Przyrodniczy w Poznaniu

\title{
Dzierżawa źródłem poprawy materialnych warunków produkcji trzody chlewnej w Polsce w kontekście doświadczeń państw UE
}

\section{Tenancy as a Source of Improvement the Material Conditions of Polish Pig Productionin in the Context of EU Countries' Experiences}

\begin{abstract}
Synopsis. Celem opracowania jest omówienie dzierżawy, jako alternatywnej drogi wykorzystania potencjału majatkowego sektora produkcji trzody chlewnej w Polsce. Tłem rozważań były zmiany zachodzące w sektorze trzodowym w okresie od 2010r. Realizując cel wykorzystano dostępne publikacje GUS, w tym dane Powszechnego Spisu Rolnego 2010, które analizowano poddając je dyskusji z opracowaniami innych autorów, w tym zagranicznych. Postawiono tezę, że zmniejszanie się stanu pogłowia i liczby utrzymujących je gospodarstw wpływa na „uwalnianie” potencjału produkcyjnego, który może zostać wykorzystany przez inne podmioty realizujące produkcję zgodną $\mathrm{z}$ wymaganiami środowiskowymi, dobrostanem zwierząt oraz przy akceptacji lokalnych społeczności.
\end{abstract}

Słowa kluczowe: produkcja trzody chlewnej, warunki materialne produkcji, dzierżawa rolnicza,

\begin{abstract}
The aim of this study is to discuss tenancy as an alternative way to use the pig sector's property potential in Poland. The background The background of the considerations were changes occurring in the pig sector in the period from 2010. In order to achieve this objective, available CSO (GUS) publications, including Census General Agricultural Census 2010, were used, which were analysed by submitting discussions with the studies of other authors, including foreign ones. The thesis was also made that the decrease in both the number of livestock and the number of farms maintaining it influences the "release" of production potential, which can be used to develop production while maintaining environmental requirements, animal welfare and obtaining social acceptance.
\end{abstract}

Key words: pig production, material conditions of production, agriculture tenancy

JEL Classification: K39, P23, Q15

\section{Wprowadzenie}

Instytucja dzierżawy umożliwia zarówno powiększenie areału gospodarstwa rolnego jak i zwiększenie dochodu, jaki można z takiego gospodarstwa uzyskać. Są to dwa podstawowe cele, w jakich od kilkudziesięciu lat dzierżawa wykorzystywana jest między innymi w krajach zachodnioeuropejskich oraz USA (Bardhan, 1979). Kluczowe znaczenie dla rozwoju instytucji dzierżawy gruntów rolnych w Europie Zachodniej miało powstanie Europejskiej Wspólnoty Gospodarczej i podjęcie przez nią wspólnej dla krajów

\footnotetext{
${ }^{1}$ dr, Katedra Prawa i Organizacji Przedsiębiorstw w Agrobiznesie UP w Poznaniu, ul. Wojska Polskiego 28, 60-637 Poznań, e-mail: mkozera@up.poznan.pl; https://orcid.org/0000-0002-9245-0548

${ }^{2}$ dr, Katedra Prawa i Organizacji Przedsiębiorstw w Agrobiznesie UP w Poznaniu, ul. Wojska Polskiego 28, 60-637 Poznań, e-mail: izabela.hasinska@up.poznan.pl
} 
członkowskich polityki rolnej (Jurcewicz, Kozłowska, Tomkiewicz, 1995; Vitikainen 2004). Konkretyzację założeń tej polityki zawarto w tzw. planie Mansholta z 1968, który wskazuje kierunki zmian w zakresie dzierżaw gruntów rolnych i m.in. proponuje ich przekształcenie w kierunku ochrony praw dzierżawcy oraz umożliwienia nabycia własności dzierżawionych gruntów. Pomimo to, instytucja dzierżawy gruntów rolnych na płaszczyźnie europejskiej nie została kompleksowo uregulowana, a jej regulację pozostawiono w kompetencji poszczególnych państw członkowskich (Czechowski, Lichorowicz, 1999; Sklenicka, Molnarova i in., 2015).

Przekształcenia na płaszczyźnie ustrojowej i gospodarczej, jakie miały miejsce w Polsce po roku 1989 istotnie wpłynęły na kierunek kształtowania ekonomicznospołecznych tendencji w rozwoju instytucji dzierżawy. Wraz z upływem lat cieszy się ona rosnącą popularnością (Ziętara, 2006), mimo że wciąż wskazuje się na konieczność dopracowania rozwiązań prawnych w tym zakresie (Lichorowicz, 2010). Samo pojęcie dzierżawy zostało uregulowane w art. 693-709 Kodeksu cywilnego, przy czym regulacja ta ma charakter ramowy i zawiera odesłanie do odpowiedniego zastosowania przepisów o najmie, tj. art. 659-692 Kodeksu cywilnego.

Celem niniejszego opracowania, jest omówienie dzierżawy, jako alternatywnej drogi wykorzystania potencjału majątkowego sektora trzodowego, tym bardziej, że ulega on głębokim przekształceniom związanym zarówno z poziomem produkcji, jak i strukturą podmiotową. Postawiono tezę, że zmniejszenie się w okresie od 2010 r. do chwili obecnej stanu pogłowia oraz liczby utrzymujących je gospodarstw wpłynęło na „uwolnienie” możliwego do wykorzystania potencjału produkcyjnego. Potencjał ten mógłby ułatwić spełnienie szeregu wymagań środowiskowych i społecznych większych producentów pod warunkiem udostępnienia go w drodze dzierżawy. Badając problem wskazano na istniejące ograniczenia $\mathrm{w}$ tym zakresie wynikające $\mathrm{z}$ prawodawstwa oraz praktyki monitorowania zawieranych umów dzierżawy nieruchomości rolniczych w Polsce.

\section{Materiał i metoda}

Prezentowane opracowanie ma charakter przyczynkowy i nawiązuje do problemów przemian strukturalnych zachodzących $\mathrm{w}$ rolnictwie oraz konieczności utrzymania konkurencyjności polskiego rolnictwa nie tylko na rynku europejskim, ale również poza jego granicami. Analizy zawarte w opracowaniu poprzedzono i uzupełniono przeglądem literatury przedmiotu, w tym opracowań autorów zagranicznych, związanej z problemem dzierżawy rolniczej, prawodawstwa $\mathrm{z}$ zakresu dzierżawy w rolnictwie oraz ekspertyz związanych z sektorem trzodowym. Za informacje wyjściowe o potencjalne majątkowym sektora produkującego trzodę chlewną przyjęto dane Powszechnego Spisu Rolnego 2010 r., mimo ich historycznego już charakteru. Wykorzystano także dostępne dane statystyki publicznej związane z rolnictwem, publikowane przez Główny Urząd Statystyczny. Konkluzje z przeprowadzonych badań zaprezentowano w formie opisowej.

\section{Dyskusja i wyniki}

Produkcja trzody chlewnej w Polsce w ostatniej dekadzie podlegała głębokim przemianom. Powodowały je zarówno czynniki ekonomiczno-społeczne, jak 
i technologiczne i prawne. Ich najbardziej widocznym i mierzalnym efektem stały się: redukcja stanu pogłowia zwierząt, zmniejszenie liczby gospodarstw, oraz przekształcenia w strukturze organizacyjnej całego sektora (Kozera-Kowalska, 2017). Utrwaleniu uległo terytorialne rozmieszczenie produkcji trzody, prowadzące do jej koncentracji w tzw. polskim zagłębiu trzodowym (Kopiński, 2014; Augustyńska, 2017). Dominującą pozycję w tym zagłębiu zajmuje województwo wielkopolskie dostarczające na rynek niemal $30 \%$ produkowanych $\mathrm{w}$ kraju świń, a do tzw. wielkiej piątki należą również województwa kujawsko-pomorskie, mazowieckie, łódzkie oraz lubelskie. Łącznie, województwa te dostarczały na rynek niemal 70\% rocznej polskiej produkcji trzody (Rocznik Statystyczny Rolnictwa, 2016).

Tabela.1. Zmiany poziomu produkcji trzody chlewnej w Polsce w wybranych latach

Table. 1. Changes in the level of pig production in Poland in selected years

\begin{tabular}{|c|c|c|c|c|c|c|c|c|}
\hline \multirow[t]{2}{*}{ Wyszczególnienie } & \multicolumn{3}{|c|}{ Pogłowie (w 1000 szt) } & \multicolumn{2}{|c|}{$\begin{array}{c}\text { Zmiany stanu } \\
\text { pogłowia } \\
(2005=100)\end{array}$} & \multicolumn{3}{|c|}{ Miejsce w rankingu } \\
\hline & 2005 & 2010 & 2015 & 2010 & 2015 & 2005 & 2010 & 2015 \\
\hline Dolnośląskie & 441,5 & 300,7 & 210,3 & 68,1 & 47,6 & 13 & 14 & 13 \\
\hline Kujawsko-pomorskie & 2151,2 & 1789,5 & 1325 & 83,2 & 61,6 & 2 & 2 & 1 \\
\hline Lubelskie & 1269,3 & 997,0 & 574,6 & 78,5 & 45,3 & 5 & 5 & 6 \\
\hline Lubuskie & 257,1 & 164,1 & 143,8 & 63,8 & 55,9 & 16 & 16 & 16 \\
\hline Łódzkie & 1363,5 & 1308,2 & 1027,8 & 95,9 & 75,4 & 4 & 4 & 3 \\
\hline Małopolskie & 494,6 & 356,7 & 190 & 72,1 & 38,4 & 11 & 12 & 14 \\
\hline Mazowieckie & 2026,6 & 1438,0 & 973,6 & 71,0 & 48,0 & 3 & 3 & 4 \\
\hline Opolskie & 743,1 & 601,2 & 412,4 & 80,9 & 55,5 & 9 & 8 & 8 \\
\hline Podkarpackie & 368,4 & 296,3 & 166,9 & 80,4 & 45,3 & 15 & 15 & 15 \\
\hline Podlaskie & 873,8 & 552,8 & 337,2 & 63,3 & 38,6 & 8 & 9 & 9 \\
\hline Pomorskie & 1049,8 & 845,1 & 761,6 & 80,5 & 72,5 & 6 & 6 & 5 \\
\hline Śląskie & 423,4 & 348,8 & 251,6 & 82,4 & 59,4 & 14 & 13 & 11 \\
\hline Świętokrzyskie & 454,2 & 381,9 & 230,9 & 84,1 & 50,8 & 12 & 10 & 12 \\
\hline Warmińsko-mazurskie & 880,6 & 670,1 & 525,4 & 76,1 & 59,7 & 7 & 7 & 7 \\
\hline Wielkopolskie & 4818,5 & 4813,3 & 1214,1 & 99,9 & 25,2 & 1 & 1 & 2 \\
\hline Zachodniopomorskie & 496,8 & 380,7 & 294,7 & 76,6 & 59,3 & 10 & 11 & 10 \\
\hline Polska & 18112,4 & 15244,4 & 11639,8 & 84,2 & 64,3 & - & - & - \\
\hline
\end{tabular}

Źródło: RS Rolnictwa 2007, 2013 oraz 2016, GUS, Warszawa.

Koncentracja produkcji w zagłębiach produkcyjnych wywołuje nasilającą się krytykę społeczną powodowaną wzrostem liczebności stad w jednej lokalizacji. Krytykę tę ułatwia brak skutecznych uregulowań prawnych, zwłaszcza w przedmiocie warunków budowy i rozbudowy budynków inwentarskich, o które rolnicy walczą od lat. Racjonalne rozwiązania $\mathrm{w}$ tym zakresie są jednak niezbędne między innymi ze względu na stopień zużycia rolniczych środków trwałych (oscylujący od lat wokół 73\%) oraz relatywnie niskiej, a przy tym zmiennej skłonności rolników do inwestowania (tab. 2).

Ograniczona skłonność do inwestycji w większości gospodarstw produkujących trzodę chlewną wynika z utrzymującej się od lat niskiej opłacalności tego kierunku chowu. Skutkuje to brakiem lub niewystarczającą akumulacją kapitału, który mógłby zostać przeznaczony na inwestycje. W tej sytuacji wielu rolników rezygnuje $\mathrm{z}$ dalszej produkcji zmieniając kierunek działalności na inny, lub całkowicie rezygnuje z działalności rolniczej. 
W gospodarstwach „rezygnujących” pozostają jednak grunty, budynki i budowle inwentarskie, które mimo stopnia zużycia mogą być dalej wykorzystywane.

Tabela 2. Wybrane charakterystyki środków trwałych w rolnictwie w Polsce

Table 2. Selected characteristics of fixed assets in polish agriculture

\begin{tabular}{l|rrr}
\hline \multirow{2}{*}{ Wyszczególnienie } & \multicolumn{3}{c}{ Lata } \\
\cline { 2 - 4 } & \multicolumn{1}{c}{2005} & \multicolumn{1}{c}{2010} & 2015 \\
\hline Wartość brutto środków trwałych* (w mln zł) & 118191,0 & 141894,0 & 151396,0 \\
Inwestycje w środki trwałe (w mln) & 2962,0 & 137375,0 & 5303,9 \\
Stopień zużycia środków trwałych (\%) & 70,0 & 74,3 & 73,7 \\
\hline * w bieżących cenach ewidencyjnch & \multicolumn{2}{c}{}
\end{tabular}

Źródło: RS Rolnictwa 2007, 2013 oraz 2016, GUS, Warszawa.

Problematyczne jest ustalenie ich faktycznej liczby. Bieżąca inwentaryzacja sektora $\mathrm{w}$ tym zakresie jest $\mathrm{w}$ zasadzie niemożliwa, $\mathrm{z}$ wyjątkiem wyrywkowo prowadzonych kontroli instytucjonalnych (np. zapowiadanej w 2018 kontroli NIK oraz Europejskiego Trybunału Obrachunkowego), lub wycinkowych projektów badawczych. Informacją wiążąca, mimo upływu lat pozostają dane Powszechnego Spisu Rolnego z $2010 \mathrm{r}$. stanowiąc jedyne bazowe źródło danych o wyposażaniu gospodarstw w budynki i budowle inwentarskie. Sytuacja ta bardzo utrudnia szacowanie potencjału możliwego do powtórnego wykorzystania do produkcji trzody chlewnej. Tymczasem ustalenie stopnia wykorzystania pozostających w dyspozycji gospodarstw stanowisk umożliwiłoby nie tylko ocenę aktualnego stanu, ale też przyszłych możliwości zagospodarowania uwalnianego potencjału majątkowego. Jak wynika z przeprowadzonych analiz, w samych tylko województwach „Zagłębia trzodowego" potencjał budynków inwentarskich użytkowanych w produkcji świń wykorzystywany był w 2010 r. zaledwie w połowie. Najwyższy poziom jego wykorzystania występował w woj. wielkopolskim (66\%) i łódzkim $(60,7 \%)$, kujawskopomorskim $(57,8 \%)$, lubuski $(53,4 \%)$ oraz mazowieckim $(52 \%)$. Zbliżony stopień wykorzystania odnotowano ponadto $\mathrm{w}$ województwach opolskim i śląskim. Znaczący spadek stanu pogłowia w latach 2010 - 2015 (z 14,7 mln szt. w 2010 r. do 10,5 mln szt. w 2015 r.) oraz zmiana liczby gospodarstw utrzymujących świenie w Polsce (z 397,7 w 2010 r. do 172,2 tys. w 2015 r.) sugerują że stopień wykorzystania stanowisk w wielu województwach również uległ ograniczeniu (Charakterystyka gospodarstw..., 2010; Charakterystyka gospodarstw..., 2016; PSR, 2010). Może to oznaczać, że w kraju istnieją duże niewykorzystne zasoby majątkowe zaplecza inwentarskiego dostosowanego do produkcji świń, które mogłyby zostać ponownie przywrócone do użycia dla zwiększenia możliwości produkcyjnych sektora. Dzialanie takie stworzyłoby możliwość zapobieżenia nadmiernej koncentracji zwierząt w podmiotach o dużej skali produkcji prowadzonej ,jednoobiektowo". Pozwoliłoby jednoczesnie zachowć wymogi ochrony środowiska i dobrostanu zwierząt oraz uzyskać akceptację społeczną rozwoju produkcji trzody chlewnej, a przynajmniej ograniczenie dezaprobaty w tym zakresie. Odpowiednio monitorowana instytucja dzierżawy umożliwiłaby zatem odejście od dominujacego obecnie „jednoobiektowego" systemu produkcyjnego na rzecz systemu „wieloobiektowego" tj. tworzenia gospodarstw o wielu budynkach inwentarskich, pozostających w pewnym oddaleniu od siebie. Atutem takiego rozwiązania jest możliwość zawarcia dzierżawy na czas oznaczony oraz możliwość otrzymania za nią wynagrodzenia, które mogłoby stanowić wsparcie dochodów gospodarstwa rezygnującego z prowadzenia produkcji. Wobec braku 
danych statystycznych trudno dowieść w sposób jednoznaczny tezy o skuteczości społeczno-ekonomicznej takich działań. Argumentami na jej popracie mogą być obserwowane zmiany organizacyjne produkcji, w tym umacnianie się chowu nakładczego, ograniczenia produkcji w cyklu zamkniętym, czy spadek wielkości krajowej produkcji prosiąt (Blicharski, Hammermeister, 2014). Ponadto uwalniany potencjał majątkowy w konsekwencji wychodzenia $\mathrm{z}$ rynku gospodarstw zaprzestających produkcji lub zmieniających jej kierunek, można i należy wykorzystać kierując się zasadą racjonalnego gospodarowania, która od zawsze obecna jest w działalności rolników (Czarny, Śledziewska, 2015).

Wobec szeregu barier ekonomicznych, społecznych oraz prawnych związanych z rozwijaniem produkcji zwierzęcej i jej koncentracją w gospodarstwach największych (1000 szt. i więcej) alternatywą może stać się dzierżawa gruntów i obiektów gospodarstw opuszczających sektor. Doświadczenia krajów unijnych wskazują na istotną rolę, jaką odgrywa ta forma korzystania z nieruchomości rolnych w umacnianiu i rozwoju produkcji zwierzęcej (w tym trzody chlewnej), w takich krajach jak np. Dania i Holandia. Nie tylko w warunkach polskich dzierżawa stanowi rozwiązanie zapewniające korzyści dla obu stron tj. umożliwia zwiększenie produkcji z zachowaniem wymagań środowiskowych dla dzierżawiącego oraz zapewnienie stałego przychodu dla wydzierżawiającego. To rozwiązanie zapewniające korzyści dla obu stron tj. umożliwiające zwiększenie produkcji z zachowaniem wymagań środowiskowych dla największych oraz zapewnienie stałego przychodu z dzierżawy dla rezygnujących (Ravenscroft, Gibbard, Markwell, 1999). Oszacowanie skali możliwych przesunięć wymagałoby jednak poznania aktualnego i faktycznego stanu zasobów, jakimi dysponują gospodarstwa produkujące trzodę chlewną $\mathrm{w}$ Polsce, jak i gruntownej analizy sytuacji $\mathrm{w}$ otoczeniu wraz $\mathrm{z}$ przewidywaniem, a częściowo również kreowania nadchodzących zmian (Kononiuk, 2012).

W krajach europejskich nadal aktualny pozostaje podział na model protekcjonistyczny i liberalny dzierżawy rolniczej. Model protekcjonistyczny obowiązuje we Francji, Holandii, Hiszpanii czy Belgii. Zakłada on szczególny status dzierżawy rolniczej obowiązujący ex lege wszystkich dzierżawców i wydzierżawiających. Ponadto, zasadnicze kwestie dotyczące dzierżawy zawarte są $\mathrm{w}$ powszechnie obowiązujących przepisach prawa (Winkler, 2011). Natomiast liberalny model dzierżawy jest realizowany w Niemczech, Danii, Austrii, Grecji, Turcji, Luksemburgu oraz Wielkiej Brytanii (Maye, Ilbery, Watts, 2009; Pikalo, 1986; Consultation, 2004). W jego ramach treść umowy dzierżawy ustalana jest przez same strony, a ustawodawca $\mathrm{w}$ marginalnym stopniu ingeruje w ułożenie tego stosunku. Są również kraje, w których funkcjonuje tzw. mieszany model dzierżawy, w ramach którego występują zarówno elementy jednakowo uregulowane, jak i pozostawione do dyspozycji stron. Należą do nich Szwecja, Szwajcaria, Portugalia czy Włochy (Winkler, 1997; Costato, 2001). Na uwagę zasługuje też fakt, że w państwach Europy Zachodniej widoczny jest trend tworzenia szczególnego statusu prawnego dzierżawcy gruntów rolnych. Do jego uzyskania wymaga się, aby producent rolny spełnił ustawowo wyznaczone wymogi, ale po ich spełnieniu może korzystać z uprzywilejowanej ochrony prawnej, a także świadczeń socjalnych (Lichorowicz, 2010).

Trzeba zaznaczyć, że w krajowej sferze legislacyjnej kompleksowe uregulowanie instytucji dzierżawy rolniczej zostało odłożone na przyszłość (Druk sejmowy nr 3231). Natomiast w sferze faktycznego obrotu gruntami, ze względu na status wydzierżawiającego, można wyodrębnić różnice, które niejako utrudniają jednoznaczne zakwalifikowanie dzierżawy do przedstawionych powyżej modeli. Warto jednak zwrócić 
uwagę na praktyczny rozwój tej instytucji w innych krajach i skorzystać tak z dobrej praktyki legislacyjnej, jak i pozytywnych rozwiązań praktycznych. Jak wskazano powyżej m.in. we Francji z powodzeniem rozwija się protekcjonistyczny model dzierżawy. Instytucje dzierżawy reguluje tam kodeks cywilny, kodeks rolny a nadto ustawy szczegółowe. Od 1946r. francuski system dzierżawy nieruchomości ukierunkowany został $\mathrm{w}$ mniejszym lub w większym stopniu na tworzenie trwałych i rentownych jednostek. $\mathrm{Z}$ uprawnieniem do kontynuowania łączy się zarówno zdolność do podejmowania przedsięwzięć gospodarczych jak i możliwość inwestowania na dzierżawionej nieruchomości w warunkach ekonomicznie akceptowalnych oraz możliwość normalnej amortyzacji poniesionych, a niejednokrotnie bardzo wysokich nakładów finansowych (Compiegne, 1999). Korzystne zmiany w przepisach, które pozwalają zachować równowagę pomiędzy uprawnieniami dzierżawcy i wydzierżawiającego stanowią zachętę do korzystania $\mathrm{z}$ tej instytucji także wśród osób, które dotąd preferowały inne sposoby gospodarowania gruntami. Kolejną wartą uwagi dobrą praktyką legislacyjną we Francji jest tworzenie i dostosowywania przepisów do aktualnych trendów i potrzeb w rolnictwie np. regulacja dzierżawy ekologicznej.

Tabela. 3. Liczba umów dzierżawy gruntów z Zasobu WRSP oraz ich obszar według województw (stan na 30.06.2017)

Table. 3. Number of land lease agreements from the WRSP Resource and their area by voivodships (as at 30/06/2017)

\begin{tabular}{|c|c|c|c|}
\hline Wyszczególnienie & $\begin{array}{c}\text { Liczba umów } \\
\text { dzierżawy (szt.) }\end{array}$ & $\begin{array}{l}\text { Powierzchnia gruntów } \\
\text { (ha) }\end{array}$ & Powierzchnia/umowę \\
\hline Dolnośląskie & 7966 & 150015 & 18,8 \\
\hline Kujawsko-pomorskie & 3943 & 69557 & 17,6 \\
\hline Lubelskie & 6714 & 24139 & 3,6 \\
\hline Lubuskie & 4800 & 70880 & 14,8 \\
\hline Łódzkie & 387 & 12477 & 32,2 \\
\hline Małopolskie & 1086 & 7586 & 7,0 \\
\hline Mazowieckie & 1282 & 17651 & 13,8 \\
\hline Opolskie & 2607 & 60182 & 23,1 \\
\hline Podkarpackie & 1829 & 16291 & 8,9 \\
\hline Podlaskie & 4482 & 22382 & 5,0 \\
\hline Pomorskie & 2991 & 73371 & 24,5 \\
\hline Śląskie & 2381 & 22994 & 9,7 \\
\hline Świętokrzyskie & 421 & 5322 & 12,6 \\
\hline Warmińsko-mazurskie & 5591 & 123066 & 22,0 \\
\hline Wielkopolskie & 4245 & 163190 & 38,4 \\
\hline Zachodniopomorskie & 9490 & 210892 & 22,2 \\
\hline Razem & 60215 & 1049955 & 17,4 \\
\hline
\end{tabular}

Aktualnie na gruncie krajowym dzierżawa nieruchomości rolnych staje się w podstawowym tytułem prawnym do zorganizowania i prowadzenia gospodarstw rolnych, tym bardziej, że w przeciwieństwie do transakcji kupna nie wymaga angażowania znacznego kapitału. Dla wielu rolników dzierżawa, to możliwość rozwoju prowadzonej działalności zwłaszcza uprawowej, czego ilustracją mogą być informacje Krajowego Ośrodka Wsparcia Rolnictwa (KOWR). Wynika z nich, że tylko w 2017 r. zawarto ponad 
60 tys. umów dzierżawy (na ok. 1, $05 \mathrm{mln}$ ha), co oznacza, że dzierżawą objętych zostało 76\% powierzchni ziemi pozostającej w Zasobie Własności Rolnej Skarbu Państwa (www.ksow.gov.pl). Jeśli jednak analizować średnią powierzchnię dzierżawy wielkości nie napawają optymizmem, trudno też dyskutować o procesach poprawy struktury agrarnej w kraju (tab. 3). Zwłaszcza wobec wejścia w życie ustawy o wstrzymaniu sprzedaży nieruchomości Zasobu Własności Rolnej Skarbu Państwa oraz o zmianie niektórych ustaw (Ustawa z dnia 14 kwietnia 2016 r.). Zmiany te ugruntowały dzierżawę jako podstawową formę zwiększeni zakresu prowadzonej działalności produkcyjnej bez konieczności zakupu użytkowanych gruntów. W tym przypadku dzierżawa, a zwłaszcza dzierżawa długoterminowa nieruchomości rolnych stała się istotnym instrumentem realizacji polityki rolnej państwa. Wciąż jednak, na wzór regulacji obowiązujących w krajach UE nie stanowi instrumentu przyspieszającego proces zmian generacyjnych w rolnictwie, a tym bardziej narzędzia umożliwiającego wykorzystanie uwalnianego potencjału produkcyjnego gospodarstw.

$\mathrm{Z}$ punktu widzenia celu prezentowanych rozważań oraz postawionej tezy istotne jest spostrzeżenie, że dzierżawa zwykle prezentowana jest przez pryzmat dzierżawy gruntów, znaczenie rzadziej składników majątku gospodarstw lub ich całości. Nie ułatwia to odpowiedzi na pytanie, czy sprzyja lub, czy może sprzyjać rozwojowi produkcji trzody chlewnej w kraju. Wprawdzie w województwach tworzących polskie zagłębie trzodowe średnie wielkości wydzierżawionych gruntów są większe niż w pozostałych (wielkopolskie 38,4ha, łódzkie 32,2 ha, kujawsko-pomorskie 17,6 ha, lubuskie 14,8 ha i mazowieckie 13,8 ha/1 umowę), trudno jednak wnioskować o ilości umów dzierżawy budynków inwentarskich, o której rolnicy często sami dyskutują na forach i grupach internetowych. Monitoring zjawiska utrudnia także brak obligatoryjnego prowadzenia rejestrów umów prowadzonego według kryterium przedmiotu umowy.

Zarysowana sytuacja przedstawia tylko część problemów dotykających produkcję trzody chlewnej w Polsce. Obok nich występują również bariery natury prawnej, takie jak konflikty związane $\mathrm{z}$ naruszania tradycyjnego ładu przestrzennego $\mathrm{i}$ konsensusu społecznego co do przeznaczenia terenów rolnych (Leśniak, 2016). Elementy te uzasadniają podjęcie działań zmierzających do wykorzystania uwalnianej części potencjału majątkowego gospodarstw wycofujących się z rynku i przekazywania ich w nowe użytkowanie na drodze umów dzierżawy.

\section{Podsumowanie}

Wyznacznikami zmian zachodzących w produkcji trzody chlewnej w Polsce są ciagła presja konkurencji zewnętrznej oraz malejąca opłacalność. Ponadto polscy producenci starają się sprostać rosnącym wymaganiom dobrostanu zwierząt, coraz częściej działając w warunkach radykalizującej się krytyki społecznej produkcji rolnej, związanej w części z naciskiem na ograniczanie produkcyjnego charakteru wsi. Wszystkie te procesy powodują coraz częstsze rezygnacje z prowadzenia produkcji trzody chlewnej. Jakkolwiek sytuacja ta sprzyja tworzeniu nowych struktur produkcyjnych, bardziej sprawnych organizacyjnie i skuteczniejszych ekonomicznie, w praktyce ich rozwój utrudniony jest przez obowiązujące środowiskowe regulacje prawne. W tej sytuacji starano się wykazać, że dzierżawa potencjału produkcyjnego zwalnianego przez rezygnujące $\mathrm{z}$ produkcji 
gospodarstw może stać się istotnym narzędziem wsparcia przemian sektora trzodowego w Polsce.

Wykorzystanie instytucji dzierżawy, szczególnie rozwiązań zbliżonych do modelu protekcjonistycznego, powinny sprzyjać jej ramowe i elastyczne uregulowania. Wśród ich możliwych skutków mogą znaleźć się między innymi:

1. tworzenie w drodze dzierżawy gospodarstw wieloobiektowych, spełniających wymogi dobrostanu zwierząt, nie obciążając środowiska naturalnego.

2. zasilenie dochodów rodzin rolniczych rezygnujących z produkcji trzody czynszem dzierżawnym.

3. zwiększenie kontroli państwa co do jakości utrzymania dzierżawionych gruntów i obiektów oraz wysokości czynszu dzierżawnego.

Należy podkreślić, że przedmiotem dzierżawy może być zarówno rzecz ruchoma, nieruchomość, pewien zbiór rzeczy i praw jak np. przedsiębiorstwo, gospodarstwo rolne, a także inwentarz żywy. To powoduje, że dzierżawa staje się bardzo atrakcyjną formą korzystania z cudzego prawa własności również w rolnictwie, otwierając wiele nowych dróg rozwoju poszczególnych gałęzi produkcji.

\section{Literatura}

Augustyńska, I. (2017). Regionalne zróżnicowanie wielkości i opłacalności produkcji żywca wieprzowego w Polsce w latach 2011-2016 (Regional differences in volume and profitability of pigs production in Poland in 2011-2016). Zagadnienia Doradztwa Rolniczego, 4(90), 80-92.

Bardhan, P. K. (1979). Agricultural development and land tenancy in a peasant economy: A theoretical and empirical analysis. American Journal of Agricultural Economics, 61(1), 48-57.

Blicharski, T., Hammermeister, A. (2014). Struktura stad - średnie wielkości i liczba gospodarstw produkujacych trzodę (Structure of herds - average size and number of farms producing pigs). Pobrane 20 lutego $2018 \mathrm{z}$ : http://www.kzp-ptch.pl/publikacje/publikacje-inne/42-struktura-stad-srednie-wielkosci-i-liczbagospodarstw-produkujacych-trzode.

Charakterystyka gospodarstw rolnych w 2010 r. (Characteristics of farms in 2010) oraz Charakterystyka gospodarstw rolnych w 2016 r. (Characteristics of farms in 2016), PSR 2010, Wyd. GUS.

Compiegne, M. (1999). Forma prawna dzierżawy: prezentacja ogólna - zalety - wady, w: Zagospodarowanie ziemi we Francji i w Polsce, Materiały pokonferencyjne (Legal form of lease: general presentation advantages - disadvantages, in: Land development in France and in Poland, Post-conference materials) Warszawa.

Consultation on changes to the Agricultura Holdings Act 1986 and the Agricultural Tenancies Act 1995 (2004). Pobrano z: http://www.defra.gov.uk.

Costato, L. (2001). Corso di diritto agrario (Course in agricultural law). Giuffre, Milano.

Czechowski, P., Lichorowicz A. (1999). Dzierżawa gruntów rolnych w świetle standardów europejskich (Lease of agricultural land in the light of European standards) Podatki i Prawo Gospodarcze Unii Europejskiej, 6, 2-5.

Jurcewicz, A., Kozłowska, B., Tomkiewicz, E. (1995). Polityka rolna Wspólnoty Europejskiej w świetle ustawodawstwa i orzecznictwa (Agricultural policy of the European Community in the light of legislation and jurisprudence). Warszawa.

Kononiuk, A. (2012). Metoda scenariuszowa w antycypowaniu przyszłości (Scenario method in future anticipating). Organization and Management, 2, 33-48.

Kopiński, J. (2014). Trendy zmian głównych kierunków produkcji zwierzęcej w Polsce w okresie członkostwa w UE (Trends of changes of the main kinds of animal production in Poland in the period of its membership in the UE). Prace Naukowe Uniwersytetu Ekonomicznego we Wrocławiu, 361, 117-129.

Kozera-Kowalska M. (2017): Reorganizacja sektora trzodowego jako warunek utrzymania pozycji konkurencyjnej Polski na rynku UE (Reorganization of the pig sector as a condition for maintaining Poland's competitive position on the EU market). W: Wyzwania na rynku żywca wieprzowego w Polsce. Red. nauk. Elżbieta Jadwiga Szymańska. Wydawnictwo SGGW Warszawa, 15-24 
Leśniak, D. (2016). Bariery prawne dla rozwoju produkcji trzody chlewnej w Polsce (Legal barriers to the development of pig production in Poland). W: Perspektywy i wyzwania dla rozwoju produkcji trzody chlewnej w Polsce. Opracowanie i redakcja naukowa Michał Thlon, Uniwersytet Ekonomiczny w Krakowie, 109-122

Lichorowicz, A. (2010). Potrzeba prawnego uregulowania dzierżawy rolnej w Polsce (na podstawie doświadczeń krajów Unii Europejskiej) (The need for legal regulation of agricultural lease in Poland (based on the experience of European Union countries)). Przeglad Prawa Rolnego, 2(7), 63-78.

Lorencowicz, E., Włodarczyk, A. (2009). Budownictwo inwentarskie w Polsce-stan i tendencje zmian (Livestock construction in Poland - status and trends of changes). Acta Sci. Pol., Technica Agraria, 8(1-2), 11-22.

Maye, D., Ilbery, B., Watts, D. (2009). Farm diversification, tenancy and CAP reform: Results from a survey of tenant farmers in England. Journal of Rural Studies, 25(3), 333-342.

Pikalo, A. (1986). Das neue Landpachtrecht (The new land lease law). Neue Juristische Wochenschrift, 23, $1472-1478$

Ravenscroft, N., Gibbard, R., \& Markwell, S. (1999). Private Sector Agricultural Tenancy Arrangements in Europe: Themes and Dimensions, a Critical Review of Current Literature (No. 28). Land Tenure Center, University of Wisconsin-Madison.

Rocznik Statystyczny Rolnictwa 2007 (Statistical Yearbook of Agriculture 2007), Wyd. GUS, Warszawa.

Rocznik Statystyczny Rolnictwa 2013 (Statistical Yearbook of Agriculture 2013), Wyd. GUS, Warszawa.

Rocznik Statystyczny Rolnictwa 2016 (Statistical Yearbook of Agriculture 2016), Wyd. GUS, Warszawa.

Rozporządzenie Ministra Rozwoju Regionalnego i Budownictwa z 29 marca 2001 r. w sprawie ewidencji gruntów i budynków (Regulation of the Minister of Regional Development and Construction of March 29, 2001 on the registration of land and buildings). (Dz. U. Rok: 2015. poz. 542).

Sklenicka P., Molnarova K. J., Salek M., Simova P., Vlasak J. Sekac P., Janovskai V. (2015). Owner or tenant: Who adopts better soil conservation practices? Land Use Policy, 47, 253-261.

Strategia odbudowy i rozwoju produkcji trzody chlewnej w Polsce do roku 2030 mająca na celu poprawę funkcjonowania sektora wieprzowiny. (Strategy for the reconstruction and development of pig production in Poland by 2030 aimed at improving the functioning of the pig sector) (2013) red. T. Blicharski, A. Hammermeister. Polski Związek Hodowców i Producentów Trzody Chlewnej „Polsus”, Warszawa.

Ustaw z dnia 14 kwietnia 2016 o wstrzymaniu sprzedaży nieruchomości Zasobu Własności Rolnej Skarbu Państwa oraz o zmianie niektórych ustaw (Set on April 14, 2016 to suspend the sale of the State Treasury Property Property Reserve and to amend certain acts). (Dz.U. Rok: 2016. Pozycja: 585)

Vitikainen, A. (2004). An Overview of Land Consolidation in Europe. Nordic Journal of Surveying and Real Estate Research, 1, 25-44.

Winkler, W. (1997). Entwicklung und Handhabung des deutschen Landpachtrechts und dessen Zukunft in der EU (Development and handling of German land lease law and its future in the EU). W: Aktuelle Aspekte der Landpacht, Verträge der HLBS - Sachverständigen - Fachtagurg von 13 bis 14 November 1996 in Göttingen, Sankt Augustin, 20-21.

Winkler, W. (2011). Das Landpachtrecht in Frankreich (The land lease in France). Agrar-und Umweltrecht, $12,465-471$.

Ziętara, W. (2006). Dzierżawa jako czynnik przemian w strukturze gospodarstw (Lease as a factor of changes in the structure of farms). Zeszyty Naukowe SGGW Ekonomika i Organizacja Gospodarki Żywnościowej, $58,75-88$.

Do cytowania / For citation:

Kozera-Kowalska M., Hasińska I. (2018). Dzierżawa źródłem poprawy materialnych warunków produkcji trzody chlewnej w Polsce w kontekście doświadczeń państw UE. Problemy Rolnictwa Światowego, 18(1), 121-129; DOI: 10.22630/PRS.2018.18.1.11

Kozera-Kowalska M., Hasińska I. (2018). Tenancy as a Source of Improvement the Material Conditions of Polish Pig Productionin in the Context of EU Countries' Experiences (in Polish). Problems of World Agriculture, 18(1), 121-129; DOI: 10.22630/PRS.2018.18.1.11 